\title{
APLIKASI REGIONAL SUSTAINABLE ACCOUNT (RSA) PADA KEBERLANJUTAN PERKOTAAN DI KALIMANTAN TIMUR
}

\author{
(Regional Sustainable Account (RSA) Application \\ on Sustainabililty Urban in East Kalimantan)
}

\author{
Margiyono \\ Universitas Borneo Tarakan, Jl. Amal Lama No. 1, Tarakan, Kalimantan Utara \\ Email: Margyubt@yahoo.co.id \\ Diterima: 24 Januari 2019 \\ Direvisi: 1 Februari 2019 \\ Diterbitkan: 31 Desember 2019
}

\begin{abstract}
The development of cities in East Kalimantan Province is influenced by the endowed of natural resources owned by the region. At present, urban areas in East Kalimantan have the problem; unemployment, critical land, high crime rates, and traffic accidents. This shows that cities in East Kalimantan have economic, social, and environmental problems. This is very interesting for investigation in the perspective of sustainable development. For this reason, this study applies a more comprehensive sustainable development assessment called the Regional Sustainable Account (RSA). RSA is a technique for calculating sustainable development that combines three calculations at once namely economic calculations, environmental calculations, and social calculations. This approach is modified by Location Quotient (LQ) combined with the Geographical Information System (GIS). The results of the study show that the development in urban areas of East Kalimantan experienced intermittent imbalances; economic, environmental, and social. It is also known that, cities in East Kalimantan are included in the classification, almost sustainable up to chronic unsustainable. Recommendations on the results of studies for regional development policy makers should carry out development with the principle of balance for all dimensions. Sustainable city development requires efforts to reduce: the number of unemployed, increasing crime, the number of traffic accidents, and high divorce. Finally, efforts to immediately respond to various unsustainability issues are part of an effort to avoid more serious chain effects.

Keywords: urban development, sustainability account, unsustainability, policy response
\end{abstract}

\begin{abstract}
Abstrak
Perkembangan kota-kota di Provinsi Kalimantan Timur dipengaruhi oleh anugerah sumber daya alam yang dimiliki wilayah itu. Saat ini, perkotaan di Kalimantan Timur menghadapi permasalahan pengangguran, lahan kritis, tingginya kriminalitas, dan kecelakaan lalu lintas. Hal itu menunjukkan bahwa perkotaan di Kalimantan Timur menghadapi permasalahan ekonomi, sosial, dan lingkungan. Hal ini sangat menarik untuk dilakukan penyelidikan dalam perspektif pembangunan berkelanjutan. Untuk itu, studi ini menerapkan penilaian pembangunan berkelanjutan yang lebih komprehensif yang disebut Regional Sustainable Account (RSA). RSA adalah teknik perhitungan pembangunan berkelanjutan yang menggabungkan tiga perhitungan sekaligus yaitu perhitungan ekonomi, perhitungan lingkungan, dan perhitungan sosial. Pendekatan ini hasil modifikasi Location Quotient (LQ) yang dikombinasikan dengan Geographical Information System (GIS). Hasil studi menunjukkan bahwa pembangunan di perkotaan Kalimantan Timur mengalami ketidakseimbangan antardimensi; ekonomi, lingkungan, dan sosial. Diketahui pula bahwa perkotaan di Kalimantan Timur termasuk pada klasifikasi almost sustainable sampai dengan chronic unsustainable. Rekomendasi hasil studi untuk para pembuat kebijakan pembangunan daerah hendaknya melaksanakan pembangunan dengan prinsip keseimbangan untuk semua dimensi. Pembangunan kota yang sustainable membutuhkan upaya untuk mengurangi jumlah pengangguran, meningkatnya kriminalitas, banyaknya kecelakaan lalu-lintas, dan tingginya perceraian. Akhirnya, upaya merespons dengan segera berbagai isu unsustainability adalah bagian dari usaha untuk menghindari efek berantai yang lebih serius.

Kata kunci: pembangunan perkotaan, perhitungan keberlanjutan, ketidakberlanjutan, respons kebijakan
\end{abstract}

\section{PENDAHULUAN}

Pendekatan pembangunan wilayah dipengaruhi oleh lahirnya konsep regional science sekitar tahun 1950-an. Di dalam perkembangannya, pembangunan wilayah mengadopsi prinsip-prinsip dari pembangunan berkelanjutan, walaupun isu keberlanjutan sejatinya dimulai sejak tahun 1798 ketika Malthus mengkhawatirkan ketersediaan lahan di Inggris akibat ledakan penduduk, namun istilah keberlanjutan (sustainability) baru muncul beberapa dekade terakhir (Fauzi, 2006). Munculnya prinsip pembangunan wilayah berkelanjutan atau sustainable regional development (SRD) melibatkan berbagai pendekatan dan instrumen yang saling terkait (Giaoutzi \& Nijkamp, 1993; Clement, et al., 2003; Patterson \& Theobold, 1995; Erlinda, 2016a; dan Bakri, et al., 2016). Hal tersebut diperkuat oleh pendapat Tappeser, et al. (1999) yang menyatakan bahwa pembangunan wilayah bukan hanya konsep "tunggal" tentang perspektif spasial tetapi terdapat aspek-aspek lain yang harus diperhatikan.

Beberapa aspek pembangunan yang harus diperhatikan menurut Sorman (2007) antara lain aspek ekonomi, lingkungan, dan sosial. Berbagai aspek 
tersebut saling berkaitan karena masalah di salah satu aspek akan memengaruhi aspek lainnya. Misalkan terjadi bencana ekologi maka dapat menstimulasi ketidakstabilan sosial dan ekonomi yang berbentuk peningkatan tingkat kriminalitas, kecelakaan lalu lintas, perceraian, pengangguran, hingga perubahan pola sosial (Wen \& Cen, 2008). Tidak mengherankan apabila Lancker \& Nijkamp (2000) menegaskan perlunya penilaian keberlanjutan secara kuantitatif maupun kualitatif untuk meningkatkan presisi dalam pengambilan keputusan. Oleh karena itu, untuk mewujudkan pembangunan berkelanjutan tingkat global, nasional, regional, atau lokal, penting melakukan pengukuran secara kuantitatif atau kualitatif. Bagaimanapun pengukuran secara "mutlak" masih sulit dilakukan karena setiap negara atau masyarakat memiliki indikator dan tingkat kemajuan yang berbeda-beda (Sorman, 2007).

Implementasi penilaian keberlanjutan tersebut menghadapi banyak tantangan, terutama bagi negara-negara berkembang. Hal ini karena mereka melakukan banyak pembangunan di berbagai sisi, termasuk pembangunan wilayah, guna mengejar pembangunan ekonomi setinggi-tingginya. Oleh sebab itu, tidak jarang isu lingkungan dan sosial menjadi abai atau kurang diperhatikan. Salah satu negara berkembang dengan karakteristik geografi, demografi, sosial budaya, dan potensi sumber daya alam (SDA) yang sangat beragam adalah Indonesia. Konsep pembangunan wilayah melalui rezim otonomi daerah menjadi contoh yang sangat menarik untuk dielaborasi. Setiap provinsi, kabupaten, dan kota memiliki karakteristik berupa potensi, beban, dan orientasi pembangunan wilayah yang beragam. Dinamika antarwilayah ditunjukan oleh keterkaitan suatu wilayah dengan wilayah lain, yang ditegaskan oleh Hukum Tobler bahwa "segala sesuatu berkaitan, sementara yang terdekat kaitannya lebih besar".

Di antara provinsi-provinsi yang ada di Indonesia, Kalimantan Timur memiliki keunikan atau kelebihan tersendiri terkait dengan pembangunan wilayah yang berkelanjutan, di samping kontribusinya yang memang signifikan terhadap pertumbuhan ekonomi nasional. Struktur ekonomi Provinsi Kalimantan Timur banyak ditopang oleh sektor pertambangan. Kontribusinya mencapai 32,55 persen terhadap Pendapatan Domestik Regional Bruto (PDRB) pada tahun 2000 dan memiliki kecenderungan terus meningkat, di mana pada tahun 2015 tercatat sebesar 45,16 persen. Tingginya kontribusi sektor tersebut memengaruhi pula perkembangan usaha yang ada di sektor industri, di mana 68 persen dari industri pengolahannya berupa industri minyak dan gas bumi (migas) dan sisanya adalah industri nonmigas (BPS Kalimantan Timur, 2016).
Di sisi lain, beberapa indikator terkait keberlanjutan pembangunan wilayah menunjukkan kondisi yang relatif baik. Misalnya, berdasarkan nilai indeks pembangunan manusia (IPM) dan indeks kualitas lingkungan hidup (IKLH) Provinsi Kalimantan Timur dibandingkan provinsi lain di Indonesia ternyata masih berada di atas nilai rata-rata nasional. Untuk nilai IPM berada pada posisi 3 tertinggi nasional di samping DKI Jakarta dan DI Yogyakarta. Sebagai contoh, IPM Kalimantan Timur pada tahun 2010 nilainya mencapai 71,31 sementara IPM nasional hanya sebesar 66,53. Kemudian pada tahun 2015 Kalimantan Timur nilai indeksnya meningkat menjadi 74,17 dan IPM nasional sebesar 69,55 (BPS, 2018). Selanjutnya, untuk IKLH Kalimantan Timur pada tahun 2010 sebesar 68,63 atau lebih tinggi jika dibandingkan tingkat nasional yang hanya sebesar 59,79 (Kementerian Lingkungan Hidup, 2011). Bahkan untuk tahun 2015 nilai tersebut meningkat lebih tinggi lagi menjadi 81,15 dengan kualifikasi nilai adalah "sangat baik". Sementara pada tahun yang sama, IKLH nasional hanya memperoleh nilai sebesar 68,23 (Kementerian Lingkungan Hidup dan Kehutanan, 2017).

Meskipun demikian, Provinsi Kalimantan Timur juga menghadapi berbagai permasalahan. Permasalahan Kalimantan Timur dalam perspektif pembangunan wilayah berkelanjutan dapat dilihat dari berbagai aspek ekonomi, sosial, dan lingkungan. Dinamikanya semakin kentara ketika melihatnya dari sisi pembangunan di wilayah kabupaten dan perkotaan. Hal ini karena adanya disparitas kepadatan penduduk yang tinggi sehingga banyak memunculkan permasalahan dalam pembangunan wilayah. Pada aspek ekonomi, tingkat pengangguran di beberapa kota Kalimantan Timur ternyata cukup tinggi dibandingkan rata-rata tingkat pengangguran di Kalimantan Timur. Misalnya pada tahun 2014, tingkat pengangguran di Kota Balikpapan sebesar 7,56 persen, Samarinda sebesar 7,56 persen, dan Kota Bontang sebesar 9,38 persen (BPS Kalimantan Timur, 2015). Untuk masalah lingkungan, ternyata terdapat kenyataan bahwa luasan hutan perkotaan terhadap luasan wilayahnya relatif lebih kecil dibandingkan rata-rata provinsi, kecuali di wilayah Bontang (Pemerintah Provinsi Kalimantan Timur, 2016). Demikian juga halnya untuk permasalahan sosial, kasus kriminalitas di Kota Balikpapan, Bontang, dan Samarinda relatif lebih tinggi dibandingkan ratarata provinsi pada tahun 2015.

Memerhatikan berbagai fenomena tersebut, menarik untuk dilakukan investigasi mendalam tentang pembangunan perkotaan yang berkelanjutan yang ada di Provinsi Kalimantan Timur dengan pendekatan yang komprehensif. Pendekatan yang 
tepat menjadi krusial guna menilai sejauh apa suatu wilayah menerapkan konsep pembangunan wilayah berkelanjutan dalam mengurangi kesenjangan masyarakat. Beberapa studi pembangunan regional berkelanjutan terdahulu sebagian besar melihat dinamika internal wilayah itu, misalnya Nijkamp \& Vreeker (2000) dengan pendekatan Multikriteria (MCA) dan FLAG, Oktavianus (2014) dengan indeks komposit, Erlinda (2016b) menggunakan MCA, FLAG, dan Imprecise Decision Model (IDM). Kemudian Bakri (2017) menggunakan Principal Component Analysis (PCA), Cluster Analysis (CA), Skalogram, dan FLAG. Menurut Hansen (2001) implementasi pembangunan berkelanjutan dalam konteks regional memerlukan pendekatan baru melalui indikator pembangunan keberlanjutan regional. Menurutnya, indikator tersebut harus memenuhi (1) kesesuaian antara indikator global, regional, dan lokal, (2) aspek ekologi, sosial, dan ekonomi yang terintegrasi dan saling berkaitan, (3) spatial reference, dan (4) referensi temporary. Beberapa peneliti lain pun berupaya menghadirkan dan mengembangkan indikator-indikator lainnya. Misalnya Duran \& Paucar (2007) yang mengadopsi dari penelitian Deakin, et al., (2002) menggunakan dimensi atau aspek yang normatif namun dengan indikator yang lebih detail. Sedangkan Bakri (2017) menambahkan dimensi kelembagaan di samping dimensi utama.

Berbagai indikator tersebut memerlukan evaluasi dan penyesuaian berdasarkan dukungan data yang mampu menjelaskan kondisi masa lalu dan kemungkinan masa depan, upgrade terhadap perubahan dan pengembangan, serta pentingnya keterbandingan regional (Hansen, 2001). Berkaitan dengan isu dinamika dan keterkaitan keberlanjutan antarwilayah tersebut selama ini belum menjadi perhatian para peneliti. Oleh karena itu, studi ini mencoba mengembangkan alat analisis keberlanjutan wilayah, khususnya perkotaan, yang juga merekam dinamika wilayah lain melalui Regional Sustainable Account (RSA). Adapun permasalahan dalam penelitian ini mencakup (1) berapakah nilai dimensi ekonomi, lingkungan, dan sosial perkotaan di Provinsi Kalimantan Timur? (2) bagaimanakah keberlanjutan pembangunan perkotaan di Provinsi Kalimantan Timur? (3) apakah faktor penyebab ketidakberlanjutan perkotaan di Provinsi Kalimantan Timur? dan (4) bagaimanakah pola spasial keberlanjutan atau ketidakberlanjutan perkotaan di Provinsi Kalimantan Timur? Sedangkan tujuan studi umum adalah mengembangkan pendekatan model pembangunan yang berkelanjutan dan tujuan secara khusus adalah untuk (1) mengetahui nilai dimensi ekonomi, lingkungan, dan sosial perkotaan di Provinsi Kalimantan Timur, (2) mengetahui keberlanjutan atau ketidakberlanjutan perkotaan di Provinsi Kalimantan Timur, (3) mengetahui faktor penyebab ketidakberlanjutan perkotaan di Kalimantan Timur, dan (4) mengetahui pola spasial keberlanjutan atau ketidakberlanjutan perkotaan di Provinsi Kalimantan Timur.

\section{METODE \\ Lokasi Penelitian}

Studi ini dilaksanakan mulai bulan Juli sampai dengan Agustus 2017. Lokasi studi berada di Provinsi Kalimantan Timur, khususnya di Kota Balikpapan, Samarinda, dan Bontang.

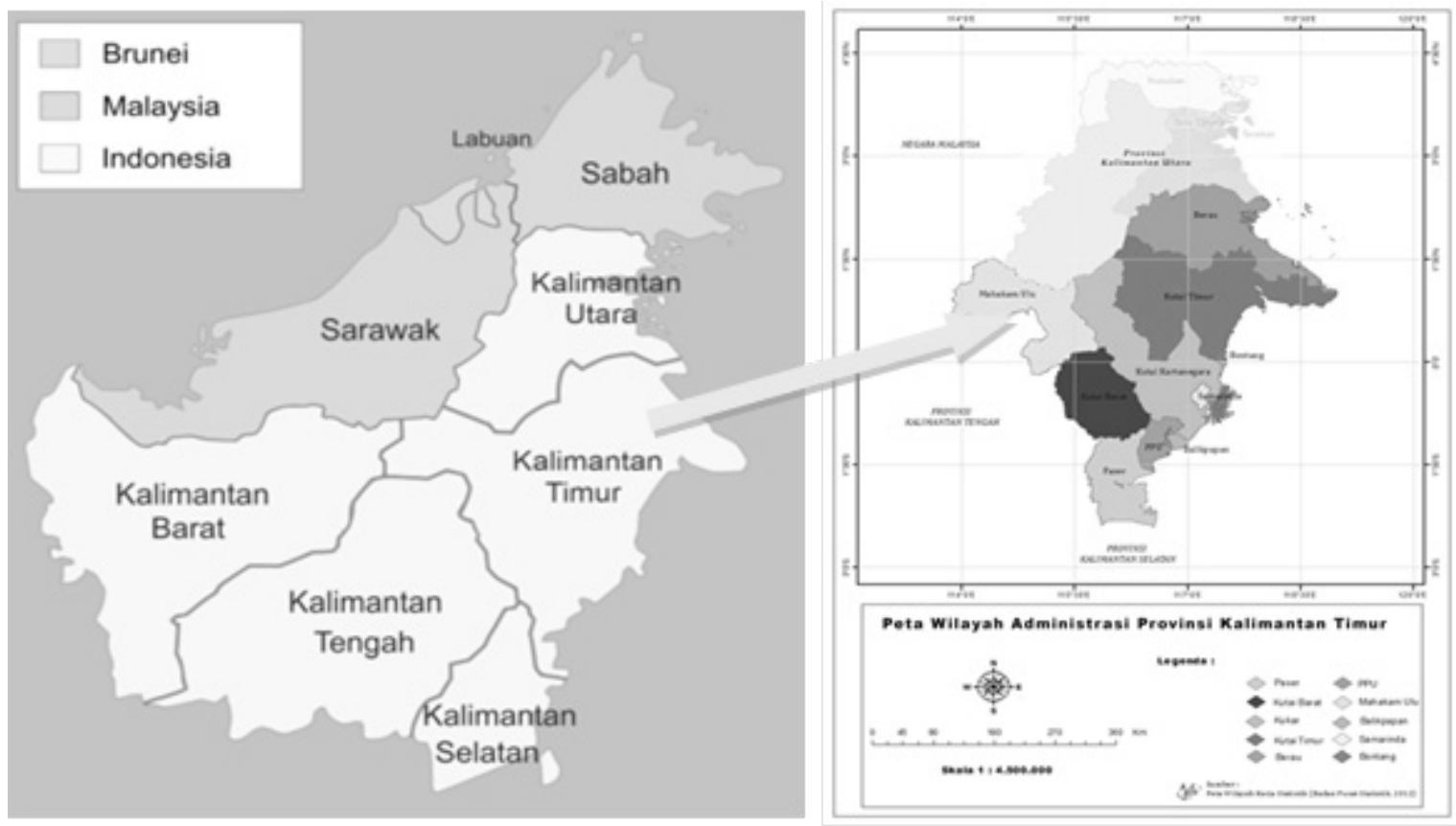

Sumber: http://bappedaKalimantan Timur .com/profil-daerah-provinsi-kalimantan-timur, 2019.

Gambar 1. Peta Lokasi Studi Provinsi Kalimantan Timur 


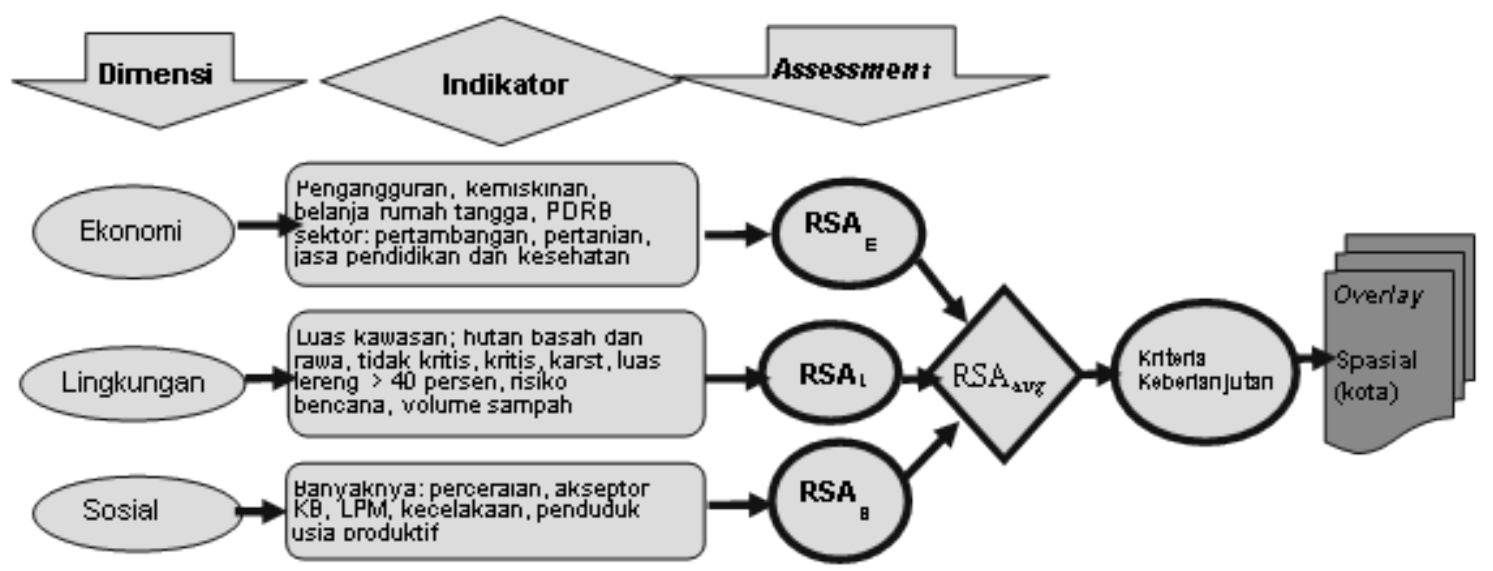

Sumber: Diadaptasi dari Mohamed, et al., 2014.

Gambar 2. Overlay Keberlanjutan Wilayah Perkotaan

Analisis Regional Sustainable Account (RSA)

Keterbandingan relatif antarwilayah sebagaimana disinggung Hansen (2001) menjadi pertimbangan penting dalam melakukan assessment pembangunan wilayah berkelanjutan karena keterkaitan antarwilayah (sesuai Hukum Tobler) sama sekali tidak bisa dihindarkan. Dinamika keterkaitan antarwilayah, terutama yang berhubungan dengan daya saing suatu wilayah dengan wilayah lain dianalisis dengan Location Quotient (LQ). Studi ini memanfaatkan logika alat analisis tersebut dengan memodifikasinya menjadi regional tools analysis sehingga lebih meaningfull dan powerfull yang kemudian disebut sebagai Regional Sustainable Account (RSA). Sebagaimana karakteristik dari LQ maka RSA juga memiliki kemampuan merekam dinamika antarwilayah. Alat ini mampu menjelaskan bahwa apabila suatu wilayah tidak berubah sedangkan wilayah lain berubah maka perubahan itu juga akan memengaruhi wilayah yang tidak berubah tersebut. Apalagi semuanya berubah maka dinamikanya akan menjadi lebih tinggi. Konstruksi pikir analisis RSA secara umum dapat diperhatikan Gambar 2.

Gambar 2 menjelaskan bahwa nilai setiap dimensi ditentukan oleh indikatornya masing-masing, di mana dalam studi ini ekonomi memiliki tujuh indikator, lingkungan sebanyak delapan indikator, dan sosial sebanyak enam indikator. Hasil setiap indikator dan setiap wilayah kemudian dirata-rata untuk menentukan tujuh kriteria keberlanjutan yaitu good sustainable, sustainable, almost sustainable, medium, almost unsustainable, unsustainable, dan chronic unsustainable. Hasil assessment tersebut akhirnya di-overlay-kan pada peta administrasi di setiap wilayah. Beberapa asumsi dalam penggunaan alat analisis RSA adalah (1) selama rentang waktu analisis tidak terjadi pergeseran struktur ekonomi, lingkungan, dan sosial, (2) wilayah yang dijadikan objek analisis beragam, (3) wilayah objek penelitian memiliki hubungan fungsional dengan wilayah pembanding sehingga perubahan pada wilayah tertentu akan memengaruhi wilayah lainnya, (4) semua dimensi memiliki bobot yang sama, dan (5) semua indikator atau variabel hanya memiliki satu hubungan yang bersifat negatif atau positif.

Rumus RSA adalah sebagai berikut:

$$
R S A= \pm \frac{F_{i k} / F_{\Sigma i k}}{G_{i K} / G_{\Sigma i K}}
$$

Di mana:

$$
\begin{aligned}
& \text { RSA : Regional Sustainable Account } \\
& \pm \text { : hubungan "positif" atau "negatif" }
\end{aligned}
$$

Kota $k$ adalah locus studi ini, yaitu Kota Samarinda, Balikpapan, dan Bontang.

Berikut disampaikan tahap-tahap analisis RSA yang terdiri dari tiga langkah yaitu pertama, menghitung nilai RSA setiap wilayah dengan tiga dimensi (ekonomi, lingkungan, dan sosial). Untuk itu, digunakan indikator seperti pada Tabel 1.

Kedua, sebagai kelanjutan langkah satu, perlu dijelaskan bahwa hasil tabulasi pada Tabel 1 memberikan tiga kemungkinan yaitu (1) nilainya nol jika jumlah nilai indikator negatif dan positifnya sama, (2) nilainya positif jika hasil penjumlahan indikator positif dan negatif lebih besar nilai positifnya, dan (3) nilainya negatif karena setelah dijumlahkan, nilai indikator negatifnya lebih besar. Untuk nilai RSA $=0$ maka masuk kriteria medium, nilai RSA pada rentang $0<\mathrm{RSA} \leq 1$ masuk kriteria almost sustainable, 
Tabel 1. Indikator Regional Sustainability Account (RSA)

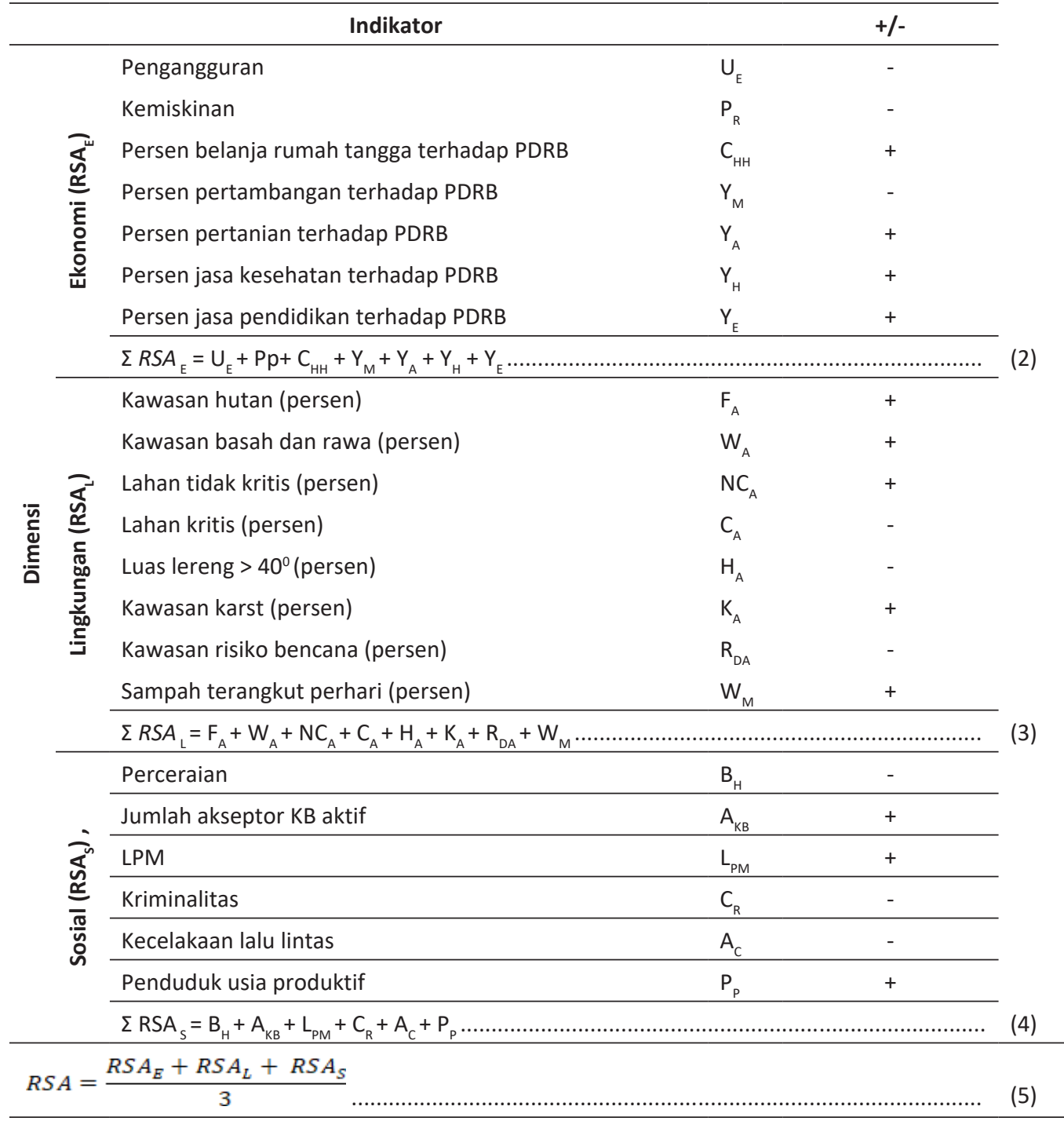

Keterangan: Variasi satuan tiap indikator lihat lampiran 1, untuk kepentingan anailisis semua indikator selanjutnya disetarakan dalam persen.

sedangkan nilai RSA pada rentang $-1 \leq \mathrm{RSA}<0$ masuk kriteria almost unsustainable.

Selanjutnya untuk nilai RSA > 1 dibagi menjadi dua dengan nilai pembatas RSA > 1avg (RSA lebih besar satu rata-rata) yang ditentukan dengan rumus sebagai berikut:

$$
\mathrm{RSA}>1 \mathrm{avg}=\frac{\sum_{1}^{N} R S A>1}{N}
$$

Di mana $N=$ jumlah kota.

Wilayah dengan RSA $\geq$ RSAavg: RSA avg $>1$ adalah masuk kriteria good sustainable dan wilayah dengan RSA < RSAavg: RSA avg > 1 maka masuk kriteria sustainable. Seperti halnya pada nilai RSA $>1$, untuk nilai RSA <-1 juga dibagi menjadi dua dengan nilai pembatas RSA $<-1$ avg yang ditentukan dengan rumus sebagai berikut:

$$
\text { RSA }<-1 \text { avg }=\frac{\sum_{1}^{N} R S A<-1}{N}
$$

Wilayah yang memiliki RSA $\leq$ RSAavg: RSA avg < -1 adalah chronic unsustainable, sementara wilayah yang memiliki RSA <-1: RSA avg < RSA maka masuk kriteria unsustainable.

Tabel 2. Kriteria Keberlanjutan (Sustainability) Wilayah

No. Nilai kelas Kriteria

\begin{tabular}{lll}
\hline 1. & $\mathrm{RSA} \geq \mathrm{RSAavg}: \mathrm{RSA}$ avg $>1$ & Good sustainable \\
2. & $\mathrm{RSA}<\mathrm{RSA} a v g: \mathrm{RSA}$ avg $>1$ & Sustainable \\
3. & $0<\mathrm{RSA} \leq 1$ & Almost sustainable \\
4. & $\mathrm{RSA}=0$ & Medium \\
5. & $-1 \leq \mathrm{RSA}<0$ & Almost unsustainable \\
6. & $\mathrm{RSA}<-1$ : RSA avg $<\mathrm{RSA}$ & Unsustainable \\
7. & $\mathrm{RSA} \leq \mathrm{RSAavg:} \mathrm{RSA}$ avg $<-1$ & Cronic unsustainable \\
\hline
\end{tabular}

Sumber: Disarikan dari penjelasan langkah dua. Sementara untuk kriteria keberlanjutan mengembangkan istilah sustainable dan unsustainable dari Wen \& Cen, 2008). 


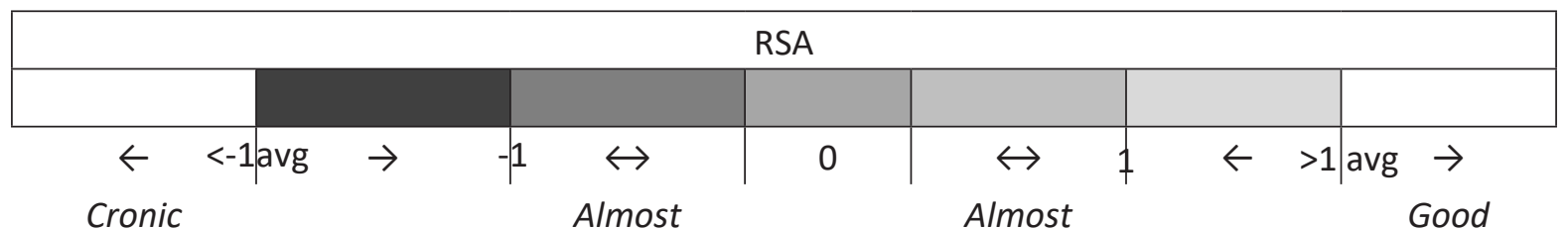

unsustainable Unsustainable Unsutainable Medium Sustainable Sustainable Sustainable

Sumber: Dikembangkan dari Pendekatan FLAG (Nijkamp \& Ouwersloot, 1996).

Gambar 3. Warna Overlay Kriteria Keberlanjutan Wilayah (Kota)

Ketiga, langkah ini terinspirasi oleh pendekatan yang dikembangkan Nijkamp dan Ouwersloot (1996) yang memberikan label warna bendera (FLAG) dari hasil analisis keberlanjutannya. Perbedaannya dengan studi ini, "warna" digunakan sebagai sustainability labelling suatu wilayah setelah diperoleh kriteria keberlanjutannya. Kriteria keberlanjutan tersebut diberi warna tertentu dan di-overlay-kan pada peta wilayah secara spasial sehingga tampilan setiap wilayah sesuai dengan kriteria keberlanjutannya dengan warna seperti pada Gambar 3.

\section{Sumber Data dan Teknik Estimasi}

Analisis RSA pada studi ini berbasis pada wilayah kota (secara administratif) dengan wilayah pembanding (regional reference) adalah wilayah Provinsi Kalimantan Timur. Sementara data yang dianalisis adalah data tahun 2014 dan tahun 2015. Untuk dimensi ekonomi dan sosial menggunakan data yang diterbitkan oleh BPS Provinsi Kalimantan Timur dan BPS Kota Balikpapan, Bontang, serta Samarinda tahun 2015 dan 2016. Kemudian untuk data dimensi lingkungan sebagian besar mengacu pada buku Informasi Kinerja Pengelolaan Lingkungan Hidup Daerah (IKPLHD) Provinsi Kalimantan Timur tahun 2016. Sedangkan data luas kawasan hutan, rawa, dan lahan basah (data atribut dari Badan Informasi Geospasial/BIG) dan luas lereng $>40^{\circ}$ (BPS Provinsi Kalimantan Timur, 2015 dan 2016) pada dokumen Kalimantan Timur Dalam Angka (KDA) tahun 2015 dan 2016. Oleh karena keterbatasan ketersediaan data lahan kritis (potensial kritis, kritis, dan sangat kritis) dan kawasan karst maka diasumsikan untuk tahun 2014 dan tahun 2015 tidak terjadi perubahan luasan.

Estimasi terhadap dimensi ekonomi terdiri dari 7 indikator dan secara operasional dibedakan menjadi tiga, yaitu (1) rasio pengangguran di suatu wilayah terhadap jumlah angkatan kerja, hasilnya kemudian dirasiokan dengan rasio pengangguran terhadap angkatan kerja pada tingkat provinsi (regional reference), (2) rasio kemiskinan terhadap jumlah penduduk di suatu wilayah dirasiokan dengan kemiskinan terhadap jumlah penduduk pada tingkat provinsi, dan (3) indikator jumlah belanja rumah tangga, kemudian PDRB sektor pertambangan, pertanian, jasa kesehatan, dan pendidikan (kelimanya) dirasiokan dengan total PDRB di suatu wilayah. Lalu hasilnya dirasiokan lagi dengan indikator yang sama pada tingkat Provinsi Kalimantan Timur.

Dimensi lingkungan terdiri delapan indikator dan tujuh indikatornya menggunakan teknik estimasi dengan merasiokan luas kawasan hutan, lahan basah dan rawa, lahan tidak kritis, lahan kritis, luasan lereng $>40^{\circ}$, dan kawasan berisiko bencana terhadap luas wilayah di setiap kota. Hasilnya lalu dirasiokan dengan indikator yang sama pada wilayah pembanding, yaitu Provinsi Kalimantan Timur. Kemudian untuk data sampah terangkut per hari data yang diperoleh adalah dalam persen, untuk memperoleh nilai RSAnya maka nilainya dibagi dengan persentase pada tingkat provinsi.

Terakhir, untuk dimensi sosial memiliki 6 indikator. Untuk teknik estimasi RSA perceraian dengan merasiokan perceraian di suatu wilayah dengan jumlah kepala keluarga, hasilnya dirasiokan dengan indikator yang sama pada level provinsi. Sedangkan untuk lima indikator lain, yaitu jumlah akseptor Keluarga Berencana (KB), Lembaga Pemberdayaan Masyarakat (LPM), jumlah kriminalitas, kecelakaan lalu lintas, dan penduduk usia produktif, dirasiokan dengan jumlah penduduk di setiap wilayah. Hasilnya juga dirasiokan dengan indikator yang sama pada daerah pembanding.

\section{HASIL DAN PEMBAHASAN \\ Analisis "Regional Sustainable Account (RSA)"}

Langkah pertama dari analisis RSA adalah menghitung nilai dimensi ekonomi, lingkungan, dan sosial dengan masing-masing indikatornya. Nilai ketiga dimensi untuk tiga kota di Provinsi Kalimantan Timur secara rinci dapat diperhatikan pada Tabel 3.

Assessment terhadap dimensi ekonomi sebagaimana ditampilkan pada Tabel 3 di mana Samarinda memperoleh nilai tertinggi dibandingkan 2 kota lainnya. Pada tahun 2014, Samarinda memperoleh nilai 6,61 dan tahun 2015 turun menjadi 5,81, walaupun nilainya masih relatif tetap tinggi. Tingginya nilai dimensi ekonomi Samarinda dipengaruhi oleh tingginya belanja rumah tangga, peran pendidikan, dan kesehatan. Hal ini tidak 
Tabel 3. Hasil Analisis RSA Perkotaan di Kalimantan Timur Tahun 2014 dan 2015

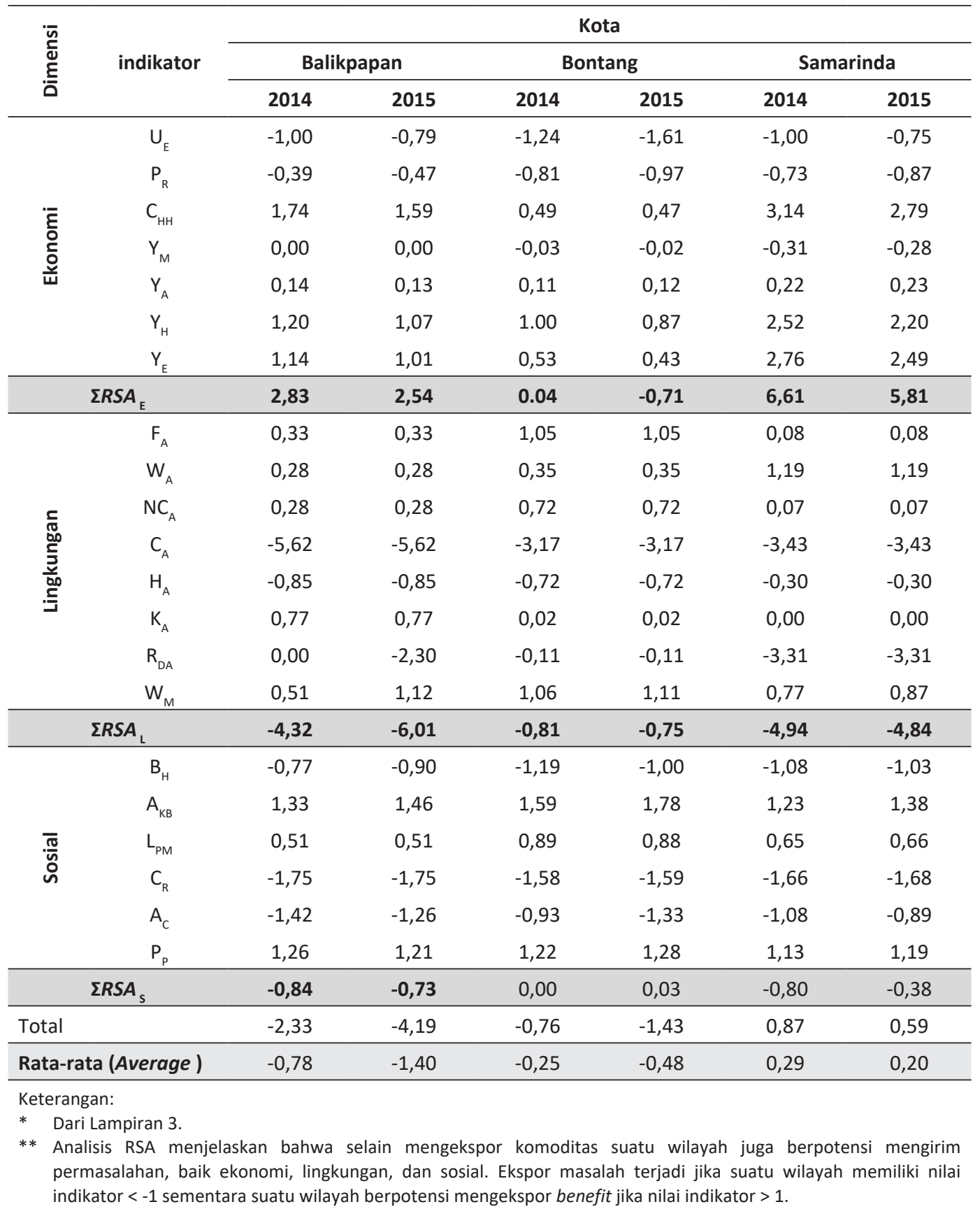

terlepas dari realitas bahwa Samarinda selain sebagai ibu kota provinsi juga sebagai pusat sosial, ekonomi, pendidikan, dan kesehatan. Banyaknya jumlah penduduk dan fasilitas perbelanjaan yang didukung dengan tingkat pendapatan tertentu turut memengaruhi tingginya belanja rumah tangga. Menurut Wen dan Cen (2008), belanja rumah tangga merupakan bagian dari indikator dimensi ekonomi yang memberikan benefit terhadap pertumbuhan ekonomi. Di sisi lain, tingginya nilai pendidikan dipengaruhi oleh banyaknya fasilitas pendidikan. Bahkan Kota Samarinda sebagai salah satu kota di Kalimantan Timur, baik sebelum maupun setelah pemakaran, menjadi kota pusat pendidikan dasar sampai dengan perguruan tinggi. Adapun untuk tingginya nilai kesehatan dipengaruhi bahwa Samarinda juga memiliki fasilitas kesehatan yang menjadi rujukan beberapa rumah sakit dari kabupaten dan kota. Di samping indikator-indikator tersebut, Samarinda berhasil mengurangi angka penganggurannya, di mana nilai pengangguran $\left(U_{E}\right)$ pada tahun 2014 sebesar $-1,00$ menjadi $-0,75$ pada tahun 2015. Akhirnya keberhasilan pembangunan ekonomi di Samarinda sesuai pernyataan dari United Nations (2013), bahwa di dalam pembangunan berkelanjutan penting memandang konsensus global terkait mengentaskan kemiskinan dan mengurangi pengangguran dengan penciptaan lapangan kerja 
yang disertai dengan pembangunan manusia melalui pendidikan dan kesehatan.

Pada Kota Balikpapan, kondisi dimensi ekonominya ternyata mirip dengan Samarinda, yaitu nilainya positif $>1$. Pada tahun 2014 dimensi ekonomi Kota Balikpapan memperoleh nilai sebesar 2,83 dan pada tahun 2015 sedikit menurun menjadi 2,54 . Sekalipun masih di bawah nilai Kota Samarinda, namun tetap masih tinggi karena secara komparatif Kota Balikpapan mampu memberikan benefit ke wilayah sekitarnya yang ditunjukan dengan nilai $\mathrm{RSA}_{E}>1$. Tingginya RSA $\mathrm{E}_{\mathrm{E}}$ Kota Balikpapan tersebut dipengaruhi oleh tingginya belanja rumah tangga, kesehatan, dan pendidikan. Hal ini terjadi karena posisi Kota Balikpapan sebagai kota terbesar dan tersibuk di Pulau Kalimantan, baik dalam aktivitas bisnis, kesehatan, dan pendidikan. Di samping itu, jika dibandingkan dengan nilai tahun 2014 dengan tahun 2015, pada Kota Balikpapan menunjukkan penurunan pengangguran, kemiskinan, dan kecilnya peran sektor pertambangan dalam struktur ekonominya. Hal ini mengindikasikan bahwa Kota Balikpapan telah berhasil melakukan transformasi struktur ekonomi seperti solusi yang ditawarkan oleh Nababan, et al. (2014) yaitu melakukan transformasi struktur ekonomi dengan berbasis pada SDA terbarukan.

Sementara itu, dimensi ekonomi Kota Bontang jika dibandingkan dengan dua kota yang lain ternyata memperoleh nilai terendah, bahkan pada tahun 2015 nilainya negatif. Kondisi ini dipengaruhi oleh menurunnya sebagian besar indikator ekonomi, misalnya pengangguran pada tahun 2014 memperoleh nilai -1,24 dan tahun 2015 menjadi $-1,61$. Pada periode yang sama, nilai kemiskinan dari $-0,81$ turun menjadi $-0,97$, dan belanja rumah tangga turun dari 0,49 menjadi 0,47. Adapun indikator yang mengalami perbaikan adalah sektor pertambangan, yaitu dari $-0,03$ pada tahun 2014 menjadi $-0,02$ pada tahun 2015.

Sebagai provinsi yang dikaruniai kelimpahan SDA, Kalimantan Timur saat ini mengalami penurunan pertumbuhan ekonomi akibat menyusutnya hasil tambang dan beban kerusakan lingkungan pasca tambang. Hasil analisis dimensi lingkungan terhadap kota-kota di Kalimantan Timur menunjukkan nilai negatif, artinya kondisi lingkungan di perkotaan berada pada situasi unsustainable. Hal itu mengindikasikan bahwa kelimpahan SDA berkecenderungan mengakibatkan resource course (Opeyemi, 2012). Hasil analisis dimensi lingkungan memperlihatkan Kota Balikpapan mengalami penurunan nilai yang cukup berarti, yaitu dari sebesar -4,32 pada tahun 2014 menjadi sebesar $-6,01$ di tahun 2015. Penyebab utama penurunan itu adalah luasnya lahan kritis $\left(C_{A}\right)$ yang ditunjukan oleh nilai RSA sebesar -5,62. Di samping keberadaan lahan kritis, Kota Balikpapan juga memiliki kawasan dengan kelerengan $>45^{\circ}\left(\mathrm{H}_{A}\right)$ yang relatif luas jika dibandingkan dua kota lainnya. Hal ini menjadi masalah lingkungan karena berpotensi terjadinya tanah longsor. Seperti pernyataan Humphreys, et al. (2015) bahwa kawasan dengan lereng yang curam memiliki tingkat risiko maksimal. Di sisi lain, Kota Balikpapan juga memiliki kawasan yang unik, yaitu Karst dengan nilai budaya dan kawasan penyedia air tawar yang melimpah (Pemerintah Provinsi Kalimantan Timur, 2015).

Dimensi lingkungan Kota Bontang dan Samarinda juga memperoleh nilai negatif. Artinya kondisinya sama dengan Kota Balikpapan. Misalnya Kota Bontang tahun 2014 memperoleh nilai -0,81, kemudian pada tahun 2015 nilainya mencapai -0,75. Sementara Kota Samarinda pada tahun 2014 memperoleh nilai sebesar -4,94 dan pada tahun 2015 menjadi -4,84. Kedua kota ini juga mengalami beban lahan kritis yang sangat tinggi, misalnya berdasarkan indikator lahan kritis $\left(C_{A}\right)$ Kota Bontang nilainya sebesar $-3,17$ dan Kota Samarinda sebesar $-3,43$. Oleh karena itu, permasalahan lahan kritis menjadi persoalan utama di perkotaan wilayah Kalimantan Timur yang tidak hanya memengaruhi dimensi ekonomi, juga menjadi beban lingkungan. Menurut Kartodihardjo dan Supriono (2000), lahan kritis adalah lahan terdegradasi yang harus direboisasi. Departemen Kehutanan (1989) juga menegaskan bahwa lahan kritis adalah lahan yang tidak mampu lagi berperan sebagai unsur produksi pertanian/kehutanan, baik sebagai media pengatur tata air, maupun sebagai perlindungan alam lingkungan.

Selain permasalahan lahan kritis, rendahnya nilai dimensi lingkungan Kota Samarinda juga dipengaruhi oleh luasnya area rawan bencana, nilainya mencapai $-3,31$. Luasnya area rawan bencana ini tidak dapat dilepaskan dari posisi topografis Kota Samarinda yang dilewati oleh aliran Sungai Mahakam, sehingga memiliki kawasan rawan bencana banjir yang terbesar dibandingkan wilayah lain di Kalimantan Timur. Satu-satunya indikator lingkungan yang memiliki nilai positif dan relatif tinggi di Kota Samarinda adalah keberadaan kawasan rawa dan lahan basah $\left(\mathrm{W}_{\mathrm{A}}\right)$, nilainya sebesar 1,19. Keberadaan kawasan ini hendaknya dijaga dari tekanan perkembangan pemukiman dan pembangunan prasarana kota lainnya karena luasan lahan basah dan rawa memengaruhi produktivitas perikanan dan kesejahteraan (Bell, 2002).

Nilai dimensi lingkungan Kota Bontang jika dibandingkan dengan Kota Samarinda dan Balikpapan adalah yang terbaik, di mana nilai negatifnya adalah terendah. Berdasarkan hasil 
analisis, indikator yang bertanda positif lebih besar satu $(>1)$ yaitu indikator pengelolaan sampah $\left(\mathrm{W}_{\mathrm{M}}\right)$ dan luasan hutan $\left(F_{A}\right)$. Namun perolehan yang relatif baik tersebut terkoreksi oleh luasnya lahan kritis. Oleh karena itu, Kota Bontang harus tetap mempertahankan sekaligus meningkatkan luasan hutan yang dimilikinya dengan memanfaatkan lahan kritis yang menjadi permasalahan ekonomi dan lingkungan tersebut. Hal ini sesuai yang dinyatakan oleh Nawir (2008) bahwa perbaikan kondisi ekologi hutan dan lahan cenderung lebih berkelanjutan untuk jangka panjang.

Terakhir, berdasarkan analisis dimensi sosial, ketiga kota di Kalimantan Timur sama-sama memperoleh nilai yang tinggi $(>1)$, terutama indikator penduduk usia produktif $\left(P_{p}\right)$ dan keluarga berencana $\left(A_{K B}\right)$. Tingginya usia produktif dalam perspektif penawaran tenaga kerja adalah bonus demografi yang menguntungkan pembangunan. Banyaknya penduduk usia produktif akan mengurangi angka ketergantungan sehingga terjadi peningkatan potensi investasi dibandingkan konsumsi (Adioetomo, 2005). Sekalipun berpotensi menjadi bonus pembangunan, namun jumlah penduduk produktif yang tinggi juga berpotensi menjadi permasalahan jika tidak terserap menjadi tenaga kerja pada sektor-sektor produksi. Untuk menghindari permasalahan ekonomi dan sosial tersebut maka penting melakukan pengendalian penduduk melalui KB. Pentingnya program KB diintensifkan guna menghindari ledakan penduduk yang menjadi permasalahan ekonomi, lingkungan, dan juga sosial. Berkaitan dengan itu Baiquni (2009) menyatakan bahwa ledakan penduduk dapat mengakibatkan eksploitasi SDA, peningkatan polusi, dan ancaman kelestarian lingkungan.

Secara umum dapat ditegaskan bahwa pembangunan sosial di perkotaan Kalimantan Timur cenderung mengalami perbaikan, walaupun nilainya masih negatif. Bahkan Kota Bontang memiliki nilai negatif pada tahun 2014 menjadi positif pada tahun 2015. Kota Balikpapan dan Samarinda pada tahun 2014 dan tahun 2015 keduanya memiliki nilai negatif walaupun tidak lebih kecil dari -1 < -1). Indikator yang paling berpengaruh terhadap dimensi sosial adalah tingginya kriminalitas dan kecelakaan lalu lintas. Selain indikator itu, dimensi sosial Kota Samarinda juga dipengaruhi tingginya perceraian $\left(B_{H}\right)$, yang ditunjukan nilai RSA sebesar -1,07 pada tahun 2014 dan menjadi -1,03 pada tahun 2015. Indikator kriminalitas, kecelakaan lalu-lintas, dan perceraian tersebut akan memengaruhi upaya pencapaian sustainable development, serta Wen \& Cen (2008) menganggap indikator tersebut sebagai biaya pembangunan. Kemudian pada indikator LPM menunjukkan bahwa peran lembaga ini di ketiga kota di Provinsi Kalimantan Timur ternyata belum optimal. Hal ini ditunjukan dengan nilainya masih relatif rendah. Keberadaan LPM penting karena berfungsi untuk menampung dan menyalurkan aspirasi masyarakat dalam pembangunan (Wirawan, 2014).

Memerhatikan hasil analisis RSA tersebut dapat dinyatakan bahwa perkotaan di Kalimantan Timur secara umum mengalami penurunan nilai untuk dimensi ekonomi dan lingkungan. Dimensi ekonomi adalah satu-satunya dimensi yang memiliki nilai positif terbesar, kecuali Kota Bontang yang mengalami penurunan nilai dari positif menjadi negatif. Penurunan nilai dimensi ekonomi untuk ketiga kota polanya sama yaitu meningkatnya jumlah kemiskinan $\left(P_{R}\right)$, menurunnya jumlah belanja rumah tangga $\left(\mathrm{C}_{\mathrm{HH}}\right)$, dan berkurangnya kontribusi sektor kesehatan $\left(\mathrm{Y}_{\mathrm{H}}\right)$ dan pendidikan $\left(\mathrm{Y}_{\mathrm{E}}\right)$ terhadap PDRB. Untuk dimensi lingkungan, ketiga kota memperoleh nilai negatif, di mana penurunan tertinggi terjadi di Kota Balikpapan. Pola persoalan lingkungan pada ketiga kota juga sama, yaitu dihadapkan pada tingginya luasan lahan kritis. Berbeda dengan dua dimensi lainnya, untuk dimensi sosial di ketiga kota di Provinsi Kalimantan Timur secara umum mengalami perbaikan, yang disebabkan oleh faktor meningkatnya jumlah akseptor $K B\left(A_{K B}\right)$ dan meningkatnya jumlah usia produktif $\left(\mathrm{P}_{\mathrm{p}}\right)$. Untuk indikator tersebut, hanya Kota Balikpapan yang mengalami penurunan nilai walaupun kecil. Perlu juga disampaikan di sini bahwa untuk mempertahankan dimensi sosial yang kondusif pada setiap kota di Kalimantan Timur maka harus mewaspadai peningkatan kriminalitas dan kecelakaan lalu lintas.

\section{Kriteria Keberlanjutan}

Kriteria keberlanjutan wilayah perkotaan dengan menggunakan kode warna pada studi ini diarahkan untuk membantu pada tataran implementansi kebijakan. Warna pembeda yang jelas akan memberikan efek peringatan dini yang lebih efektif. Labelling sustainability dengan warna ini diharapkan bisa menjadi regional sustainability alarm berbasis peta wilayah. Untuk menentukan kriteria keberlanjutan setiap wilayah digunakan nilai RSA $>1$ dan RSA < -1. Keduanya dirata-rata sebagaimana pada formula 6 dan 7 . Kota dengan nilai RSA-nya <-1 hanya satu tahun, yaitu Kota Balikpapan pada tahun 2015, nilai pembatasnya adalah nilai itu sendiri, yaitu $-1,40$. Hasil analisis RSA yang lain berada pada rentang $0<\mathrm{RSA} \leq 1$ dan $-1 \leq \mathrm{RSA}<0$ maka kriteria ketiga kota di Kalimantan Timur untuk tahun 2014 dan 2015 seperti disajikan pada Tabel 4.

Memperhatikan tampilan hasil penentuan kriteria keberlanjutan untuk kota-kota di Kalimantan 
Tabel 4. Kriteria keberlanjutan Perkotaan di Provinsi Kalimantan Timur Tahun 2014 dan Tahun 2015

\begin{tabular}{|c|c|c|c|c|c|c|}
\hline \multirow[b]{2}{*}{ Kota } & \multicolumn{3}{|c|}{ Tahun 2014} & \multicolumn{3}{|c|}{ Tahun 2015} \\
\hline & Nilai & Kriteria & $\begin{array}{c}\text { Kode } \\
\text { warna }\end{array}$ & Nilai & Kriteria & $\begin{array}{l}\text { Kode } \\
\text { warna }\end{array}$ \\
\hline Bontang & $-0,25$ & Almost Unsustainable & & $-0,48$ & Almost Unsustainable & \\
\hline Samarinda & 0,29 & Almost Sustainable & & 0,20 & Almost Sustainable & \\
\hline Balikpapan & $-0,78$ & Almost Unsustainable & & $-1,40$ & Chronic unsustanaible & \\
\hline
\end{tabular}

Timur, kriteria terbaik adalah almost sustainable dan terendah adalah chronic unsustainable. Pada tahun 2014, Kota Bontang memperoleh nilai RSA sebesar $-0,25$, kemudian tahun berikutnya 2015 nilainya sebesar -0,48, tampak bahwa mengalami penurunan tetapi masih dalam kriteria yang sama yaitu almost unsustainable. Jika dibandingkan dengan dua kota lainnya, Kota Samarinda menunjukkan nilai RSA tertinggi, yaitu 0,29 pada tahun 2014. Sementara pada tahun 2015 nilainya menurun menjadi 0,20 namun kriterianya tidak berubah karena masih berada pada kriteria almost sustainable. Penurunan nilai RSA Kota Balikpapan dibandingkan Kota Samarinda dan Bontang paling tinggi karena pada tahun 2014 memperoleh nilai -0,78 dengan kriteria almost unsustainable, kemudian tahun 2015 merosot menjadi $-1,40$ dan berada pada kriteria terendah, yaitu chronic unsustainable.

Setelah penentuan kriteria seperti penjelasan Tabel 4, langkah berikutnya adalah melakukan overlay kriteria keberlanjutan pada peta administrasi masing-masing wilayah. Untuk hasil overlay tersebut disajikan pada Gambar 4.

Sekalipun semua kota mengalami perubahan nilai, namun untuk Kota Bontang dan Samarinda masih tetap pada kriteria sebagaimana kriteria

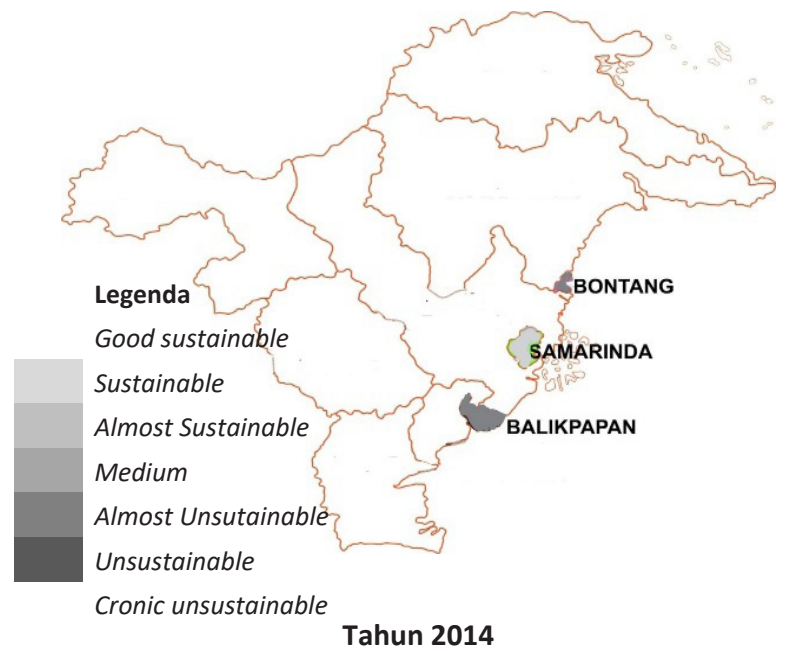

keberlanjutan masing-masing pada tahun 2014. Misalnya Kota Bontang untuk tahun 2014 dan 2015 masih tetap pada kriteria almost unsustainable, sementara Kota Samarinda juga tetap pada kriteria almost sustainable. Penurunan yang sangat tinggi terjadi di Kota Balikpapan karena pada tahun 2014 berada pada kriteria almost unsustainable namun tahun berikutnya berubah menjadi chronic unsustainable. Penurunan nilai keberlanjutan itu dipengaruhi oleh permasalahan lingkungan, terutama keberadaan lahan kritis $\left(C_{A}\right)$ yang mencapai $-5,62$ dan peningkatan luasan kawasan rawan bencana $\left(R_{D A}\right)$ yang meningkat menjadi $-2,13$. Penurunan nilai RSA-nya mengakibatkan kriteria keberlanjutan Kota Balikpapan berubah dari almost unsustainable menjadi chronic unsustainable. Sekalipun nilai dimensi ekonomi dan sosialnya positif, namun kedua dimensi itu tidak mampu mengkompensasi rendahnya nilai dimensi lingkungan. Terkoreksinya nilai ekonomi dan sosial oleh lingkungan menjelaskan bahwa untuk mencapai pembangunan yang berkelanjutan maka semua dimensi pembangunan harus dilihat secara proporsional. Artinya, tidak ada dimensi yang lebih penting antara satu dimensi dengan dimensi lainnya. Keseimbangan perlakuan setiap dimensi pembangunan (ekonomi, lingkungan, dan sosial)

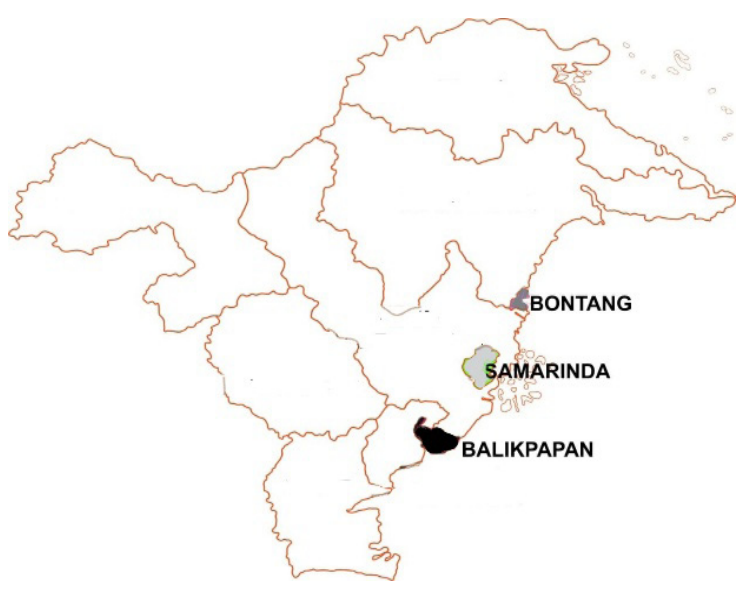

Tahun 2015

Keterangan: Berdasarkan Tabel 3 dan 4 dan Gambar 1, 2, dan 3.

Gambar 4. Overlay Kriteria Keberlanjutan Perkotaan di Provinsi Kalimantan Timur Tahun 2014 dan 2015 
akan menjamin terwujudnya pembangunan yang berkelanjutan (Sorman, 2007).

Dua kota yang lain, yaitu Kota Samarinda dan Bontang untuk dua tahun analisis tahun 2014 dan 2015 masih berada pada kriteria yang sama. Seperti halnya Kota Bontang tetap berada pada kriteria almost unsustainable, Kota Samarinda juga berada pada kriteria almost sustainable, namun demikian kualitas kriterianya menurun. Misalnya Kota Bontang pada tahun 2014 memperoleh nilai RSA sebesar -0,25, kemudian tahun 2015 menjadi lebih rendah, yaitu $-0,48$. Selanjutnya Kota Samarinda pada tahun 2014 memperoleh nilai 0,29, setelah itu tahun 2015 nilainya turun menjadi 0,20. Penurunan nilai RSA Kota Bontang dan Samarinda berada pada dimensi yang sama, yaitu ekonomi. Bedanya Kota Bontang mengalami tekanan pada peningkatan pengangguran, sementara Kota Samarinda pada sisi belanja rumah tangga, kontribusi sektor kesehatan, dan pendidikan. Penjelasan tersebut menegaskan bahwa perkotaan di Kalimantan Timur secara umum mengalami penurunan kualitas pembangunan keberlanjutan, bahkan dapat dinyatakan menuju kondisi yang unsustainable.

\section{KESIMPULAN}

Sesuai hasil analisis dan pembahasan yang telah disampaikan maka perkotaan di Provinsi Kalimantan Timur (Kota Samarinda, Bontang, dan Balikpapan) secara umum menghadapi tekanan permasalahan lingkungan, terutama berupa keberadaan lahan kritis. Di sisi lain, permasalahan lingkungan akan berakibat terkoreksinya hasil pembangunan pada dimensi ekonomi dan sosial. Di antara dua dimensi tersebut, ternyata dimensi sosial di perkotaan di Kalimantan Timur mengalami peningkatan.

Perkotaan di Kalimantan Timur mengalami penurunan nilai keberlanjutan, bahkan secara umum dapat dikatakan berpotensi menuju kondisi unsustainable. Adapun faktor-faktor yang mendorong terjadinya unsustainability di perkotaan di Kalimantan Timur adalah peningkatan pengangguran, lahan kritis, kriminalitas, dan kecelakaan lalu-lintas. Selain faktor tersebut, khusus Kota Samarinda ditambah satu faktor lagi, yaitu tingginya perceraian.

Beberapa rekomendasi yang dapat diberikan untuk mencapai prinsip pembangunan kota yang sustainable antara lain (1) pentingnya melaksanakan pembangunan kota dengan prinsip keseimbangan berdasarkan semua dimensi (ekonomi, sosial, dan lingkungan), (2) untuk menghindari kerugian ekonomi dan lingkungan yang lebih serius maka penting untuk melakukan rehabilitasi lahan dengan memanfaatkan lahan kritis secara produktif disertai upaya mengurangi aktivitas yang berpotensi meningkatkan luasan lahan kritis yang ada, (3) pemerintah kota bersama semua pihak terkait hendaknya berusaha untuk menekan tingginya jumlah pengangguran, kriminalitas, kecelakaan lalu-lintas, dan perceraian, dan (4) berbagai upaya untuk merespons dengan segera semua faktor unsustainability melalui kebijakan yang sungguhsungguh adalah bagian dari usaha untuk menghindari efek berantai ketidakberlanjutan yang lebih serius.

\section{DAFTAR PUSTAKA}

\section{Buku}

Adioetomo, S.M.S (2005). Bonus demografi, Menjelaskan hubungan antara pertumbuhan penduduk dengan pertumbuhan ekonomi. Jakarta: Fakultas Ekonomi, Universitas Indonesia.

Bell, F.W. (2002). The economic value of Salwater Marsh to Florida's Commercial Fisheris, In Letson, D. and Milon, J.W. (eds). Florida Coastal environmental resource: A guide to economic valuation an impact analysis. Florida Sea Grand College Program, USA.

Fauzi, A. (2006). Ekonomi sumber daya alam dan lingkungan, Teori dan aplikasi. Cetakan kedua, Jakarta: PT Sun.

Giaoutzi, M., \& Nijkamp P. (1993). Decision support model for regional sustainable development: An applicaton of geographic information systems and evaluation models to the Greek Sporades Islands. Avebury, England: Aldershot.

Nawir, A.A. (2008). Rehabilitasi hutan di Indonesia: Akan kemanakah arahnya setelah lebih dari tiga dasawarsa?. Dalam Nawir, A.A., Murniati, \& Rumboko L. (eds). CIFOR (Centerfor International Forestry Research).

United Nations. (2013). World economic and social survey 2013, Sustainable development challenges. New York: United Nations.

\section{Jurnal}

Baiquni, M. (2009). Revolusi industri, ledakan penduduk dan masalah lingkungan. Jurnal Sains dan Teknologi Lingkungan, 1(1), 39-59.

Bakri, B., Rustiadi, E., Fauzi, A., \& Adiwibowo, S. (2016). Assessment of regional sustainable development in Indonesia. International Journal of Humanities and Social Science, 6(11), 191-200. 
Deakin, M., Curwell, S., \& Lombardi, P. (2002). Sustainable urban development: The framework and directory of assessment methods. Journal of Environmental Assessment Policy and Management, 4(2), 171-197.

Erlinda, N. (2016a). Kebijakan pembangunan wilayah berkelanjutan di Provinsi Jambi melalui pendekatan Model FLAG. Jurnal Ekonomi \& Kebijakan Publik, 7(1), 1-14.

Patterson, A. \& Theobald, K.S. (1995). Sustainable development, Agenda 21 and the new local governance in Britain. Regional Studies, 29(8), 773-778.

Mohamed, E.S., Saleh A.M., \& Belal A.A. (2014). Sustainability indicators for agricultural land use based on GIS spatial modeling in North of SinaiEgypt. The Egyptian Journal of Remote Sensing and Space Science, 17(1), 1-15.

Nababan, Y.J., Yusman, S., Bambang, J., \& Slamet, S. (2014). Tantangan bagi pembangunan berkelanjutan di Kalimantan Timur menuju inclusive green economy. Masyarakat Indonesia, 40(2), 211-228.

Nijkamp, P., \& Vreeker, R. (2000). Methods, Sustainability assessment of development skenarios: Methodology and application to Thailand. Ecological Economics, 33, 7-27.

Opeyemi, A.Y. (2012). Empirical analysis of resource course in Nigeria, national center for technology management. International Journal Economics and Management Science, 1(6), 19-25.

Wen, Z., \& Chen, J. (2008). A cost-benefit analisys for the economic growth in China. Ecological Economics, 65, 356-366.

Wirawan. (2014). Pelaksanaan fungsi Lembaga Pemberdayaan Masyarakat (LPM) dalam pelaksanaan pembangunan di Desa Ngayau Kecamatan Muara Benkal Kabupaten Kutai Timur. eJournal Ilmu Administrasi Negara, 4(2), 1.238-1.252.

\section{Tesis dan Disertasi}

Bakri, B. (2017). Pengembangan indikator, tipologi, dan status pembangunan berkelanjutan daerah provinsi di Indonesia. Disertasi. Sekolah Pascasarjana Institut Pertanian Bogor, Bogor.

Erlinda, N. (2016b). Pembangunan wilayah berkelanjutan di Provinsi Jambi dan implikasi Model Jamrud. Disertasi. Sekolah Pascasarjana Institut Pertanian Bogor, Bogor.
Oktavianus, A. (2014). Pembangunan berkelanjutan dan hubungannya dengan modal sosial di Indonesia. Disertasi. Institut Pertanian Bogor, Bogor.

Sorman, A. (2007). A national assessment of sustainable development indicators in Turkey with examples of Local Scale Modeling using a Systems Dynamics Approach. Thesis. Lund University, Lund.

Working Paper dan Conference Paper Dipublikasikan Duran \& Paucar. (2007). Sustainability model for the Valsequillo Lake in Puebla, Mexico: combining system dynamics and sustainable urban development. Paper reports project on urban sustainability of the Valsequillo Lake in Puebla, Mexico and the Puerto Aura.

Humphreys, M., Nettelton, I., \& Leech, K. (2015). Risk assessment and management of unstabel slopes on the national forest estate in Scotland. IOP Conference Series: Earth and Environmental Science, Vol. 26, Conference 1.

Kartodihardjo, H. \& Supriono, A. (2000). Dampak pembangunan sektoral terhadap konversi dan degradasi hutan alam: Kasus pembangunan $\mathrm{HTI}$ dan perkebunan di Indonesia. Occasional Paper No. 26(I). Center for International Forestry Research (CIFOR).

Nijkamp, P., \& Ouwersloot, H. (1996). A decision support system for regional sustainable development: The FLAG Model. Dept. of Economics Free University, Amsterdam.

\section{Laporan}

BPS Provinsi Kalimantan Timur. (2015). Kalimantan Timur dalam angka 2015. Samarinda: BPS Provinsi Kalimantan Timur.

BPS Provinsi Kalimantan Timur. (2016). Produk Domestik Regional Bruto (PDRB) Provinsi Kalimantan Timur menurut lapangan usaha tahun 2011-2015. Samarinda: BPS Provinsi Kalimantan Timur.

Clement, K., Hansen, M., \& Bradley, K. (2003). Sustainable regional development: Learning from Nardic Experience. Stockholm: Nordregio 2003 (Nordregio Report 2003: 1).

Hansen, H.S. (ed.). (2001). PSSD-planning system of sustainable Development. National Environmental Research Institute, Denmark. 110 p, NERI Technical Report No. 351. 
Kementerian Lingkungan Hidup. (2011). Indeks Kualitas Lingkungan Hidup (IKLH) Indonesia tahun 2010. Jakarta. Kementerian Lingkungan Hidup.

Kementerian Lingkungan Hidup dan Kehutanan. (2017). Indeks Kualitas Lingkungan Hidup (IKLH) Indonesia tahun 2015. Jakarta. Kementerian Lingkungan Hidup dan Kehutanan.

Pemerintah Provinsi Kalimantan Timur. (2015). Dokumen Indikator Kinerja Lingkungan Hidup Daerah (IKLHD) Provinsi Kalimantan Timur. Samarinda: Pemerintah Provinsi Kalimantan Timur.
Tappeser, S.R., Lukesch R., Strati F., Sweeney G.P., \& Thierstein A. (1999). Instrument for sustainable regional development a European research project funded by DG XII. The INSURED ProjectFinal Report, Institut Fur Regionale Studien in Europa, Freburg.

\section{Website}

BPS. (2018). Data Indek Pembangunan Manusia (IPM). Diperoleh tanggal 16 Mei 2018, dari https://www.bps.go.id. 


\section{Lampiran 1:}

Tabel 5. Data untuk Analisis Regional Sustainable Account (RSA) Wilayah Perkotaan di Provinsi Kalimantan Timur

\begin{tabular}{|c|c|c|c|c|c|c|c|c|c|}
\hline & \multirow{2}{*}{ Indikator } & \multicolumn{2}{|c|}{ Balikpapan } & \multicolumn{2}{|c|}{ Bontang } & \multicolumn{2}{|c|}{ Samarinda } & \multicolumn{2}{|c|}{ Kalimantan Timur } \\
\hline & & 2014 & 2015 & 2014 & 2015 & 2014 & 2015 & 2014 & 2015 \\
\hline \multirow{10}{*}{ 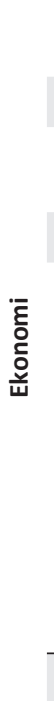 } & $\begin{array}{l}\text { Pengangguran (ada persen, } \\
\text { ada orang) }\end{array}$ & $7,56 \%$ & 16823 & $9,38 \%$ & 9524 & $7,56 \%$ & 20442 & 115986 & 115534 \\
\hline & Jumlah Angkatan Kerja & & 282671 & & 78895 & & 364309 & 1537938 & 1539491 \\
\hline & $\begin{array}{l}\text { Kemiskinan (ada persen, ada } \\
\text { orang) }\end{array}$ & $2,48 \%$ & 15000 & $5,16 \%$ & 8200 & $4,63 \%$ & 36600 & 252680 & 209990 \\
\hline & Jumlah Penduduk & 605096 & 615574 & 159614 & 163326 & 797006 & 812597 & 3969600 & 4068600 \\
\hline & $\begin{array}{l}\text { Belanja rumah tangga (juta } \\
\text { rupiah) }\end{array}$ & 18958891 & 20327946 & 4372070 & 4692869 & 23075743 & 24350805 & 8018028667 & 8635322385 \\
\hline & $\begin{array}{l}\text { Kontribusi } \\
\text { pertambangan(persen) }\end{array}$ & 0,50 & 0,50 & 1,68 & 1,08 & 15,30 & 12,50 & 50,21 & 45,16 \\
\hline & $\begin{array}{l}\text { Kontribusi pertanian } \\
\text { (persen) }\end{array}$ & 1,00 & 1,00 & 0,77 & 0,89 & 1,55 & 1,74 & 7,00 & 7,50 \\
\hline & $\begin{array}{l}\text { Kontribusi jasa kesehatan } \\
\text { (persen) }\end{array}$ & 0,53 & 0,59 & 0,44 & 0,48 & 1,11 & 1,21 & 0,44 & 0,55 \\
\hline & Kontribusi jasa pendidikan & 1,34 & 1,46 & 0,63 & 0,73 & 3,26 & 3,61 & 1,18 & 1,45 \\
\hline & PDRB (juta rupiah) & 71622701 & 74273354 & 59055313 & 58502703 & 48273715 & 50802369 & 52689678845 & 50186780313 \\
\hline \multirow{9}{*}{ 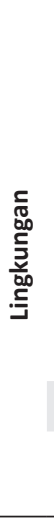 } & Kawasan hutan (ha) & 9134,77 & 9134,77 & 9397,492 & 9397,492 & 2987,86 & 2987,86 & 6993248,172 & 6993248,172 \\
\hline & $\begin{array}{l}\text { Kawasan basah dan rawa } \\
\text { (ha) }\end{array}$ & 59,16 & 59,16 & 23,94 & 23,94 & 356,88 & 356,88 & 53250,81 & 53250,81 \\
\hline & Lahan tidak kritis (ha) & 4821,84 & 4821,84 & 3998,78 & 3998,78 & 1595,84 & 1595,84 & 4330268,95 & 4330268,95 \\
\hline & Lahan kritis (ha) & 20604,52 & 20604,52 & 3703,12 & 3703,12 & 17596,24 & 17596,24 & 910819,24 & 910819,24 \\
\hline & Luas lereng $>40^{\circ}$ (ha) & 18675 & 18675 & 4974 & 4974 & 9102 & 9102 & 5433568 & 5433568 \\
\hline & Kawasan karst (ha) & 0,22 & 0,22 & 80,63 & 80,63 & 1,04 & 1,04 & $3,630,474,78$ & $3,630,474.78$ \\
\hline & Kawasan risiko bencana (ha) & 0 & $27,10 \%$ & $1,31 \%$ & $1,31 \%$ & $38,99 \%$ & $38,99 \%$ & $1,500,272,20$ & $1,500,272,20$ \\
\hline & Luas Wilayah (ha) & 51225 & 51225 & 16314 & 16314 & 71653 & 71653 & 12734692 & 12734692 \\
\hline & $\begin{array}{l}\text { Sampah terangkut per hari } \\
\text { (persen) }\end{array}$ & 35,99 & 0,8 & 75,23 & 79 & 54,57 & 61,8 & 71,19 & 580,31 \\
\hline \multirow{8}{*}{. $\frac{\pi}{5}$} & Perceraian (orang) & 1560 & 1671 & 499 & 430 & 1829 & 1986 & 7845 & 7270 \\
\hline & Jumlah KK & 212098 & 161892 & 44025 & 37565 & 178567 & 168354 & 823984 & 633730 \\
\hline & Akseptor KB aktif (orang) & 79090 & 75854 & 24868 & 24595 & 95720 & 94693 & 389008 & 342649 \\
\hline & LPM (unit) & 41 & 41 & 19 & 19 & 70 & 70 & 533 & 533 \\
\hline & Kriminalaitas (orang) & 2638 & 2526 & 629 & 610 & 3297 & 3211 & 9918 & 9545 \\
\hline & $\begin{array}{l}\text { Kecelakaan lalu lintas } \\
\text { (orang) }\end{array}$ & 225 & 143 & 39 & 40 & 226 & 133 & 1041 & 749 \\
\hline & Penduduk usia produktif & 295186 & 282671 & 75621 & 78895 & 349362 & 364309 & 1537938 & 1539491 \\
\hline & Jumlah Penduduk & 605096 & 615574 & 159614 & 163326 & 797006 & 812597 & 3969600 & 4068600 \\
\hline
\end{tabular}

Sumber: BPS Provinsi Kalimantan Timur 2015, 2016, dan 2017; BPS Kota Balikpapan, Samarinda, Bontang, 2015, 2016, dan 2017; Pemerintah Provinsi Kalimantan Timur dalam IKLHD (Informasi Kinerja Lingkungan Hidup Daerah) Provinsi Kalimantan Timur tahun 2016. 


\section{Lampiran 2:}

Tabel 6. Tabel Bantu untuk Analisis RSA Wilayah Perkotaan di Provinsi Kalimantan Timur (Rasio Tiap Indikator di Tiap Wilayah)

\begin{tabular}{|c|c|c|c|c|c|c|c|c|c|}
\hline & \multirow{5}{*}{ Indikator } & \multicolumn{6}{|c|}{ Rasio setiap Indikator di Setiap Wilayah } & \multirow{2}{*}{\multicolumn{2}{|c|}{ Pembanding }} \\
\hline & & \multicolumn{6}{|c|}{ Wilayah Kota } & & \\
\hline & & \multicolumn{6}{|c|}{ Fxy/Fx } & \multicolumn{2}{|c|}{ F.y/F } \\
\hline & & \multicolumn{2}{|c|}{ Balikpapan } & \multicolumn{2}{|c|}{ Bontang } & \multicolumn{2}{|c|}{ Samarinda } & \multicolumn{2}{|c|}{ Kalimantan Timur } \\
\hline & & 2014 & 2015 & 2014 & 2015 & 2014 & 2015 & 2014 & 2015 \\
\hline \multirow{7}{*}{$\begin{array}{l}\overline{\bar{\varepsilon}} \\
\text { 음 } \\
\text { 문 }\end{array}$} & Pengangguran & 0,0756 & 0,0595 & 0,0938 & 0,1207 & 0,0756 & 0,0561 & 0,0754 & 0,0750 \\
\hline & Kemiskinan & 0,0248 & 0,0244 & 0,0516 & 0,0502 & 0,0463 & 0,0450 & 0,0637 & 0,0516 \\
\hline & Belanja rumah tangga & 0,2647 & 0,2737 & 0,0740 & 0,0802 & 0,4780 & 0,4793 & 0,1522 & 0,1721 \\
\hline & Kontribusi pertambangan & 0,0005 & 0,0005 & 0,0168 & 0,0108 & 0,1530 & 0,1250 & 0,5021 & 0,4516 \\
\hline & Kontribusi pertanian & 0,0100 & 0,0100 & 0,0077 & 0,0089 & 0,0155 & 0,0174 & 0,0700 & 0,0750 \\
\hline & Kontribusi jasa kesehatan & 0,0053 & 0,0059 & 0,0044 & 0,0048 & 0,0111 & 0,0121 & 0,0044 & 0,0055 \\
\hline & Kontribusi jasa pendidikan & 0,0134 & 0,0146 & 0,0063 & 0,0063 & 0,0326 & 0,0361 & 0,0118 & 0,0145 \\
\hline \multirow{8}{*}{ 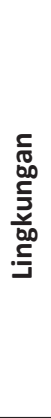 } & Kawasan hutan (persen) & 0,1783 & 0,1783 & 0,5760 & 0,5760 & 0,0417 & 0,0417 & 0,5491 & 0,5491 \\
\hline & Kawasan basah dan rawa (persen) & 0,0012 & 0,0012 & 0,0015 & 0,0015 & 0,0050 & 0,0050 & 0,0042 & 0,0042 \\
\hline & Lahan tidak kritis (persen) & 0,0941 & 0,0941 & 0,2451 & 0,2451 & 0,0223 & 0,0223 & 0,3400 & 0,3400 \\
\hline & Lahan kritis (persen) & 0,4022 & 0,4022 & 0,2270 & 0,2270 & 0,2456 & 0,2456 & 0,0715 & 0,0715 \\
\hline & Luas lereng $>40^{\circ}$ (persen) & 0,3646 & 0,3646 & 0,3049 & 0,3049 & 0,1270 & 0,1270 & 0,4267 & 0,4267 \\
\hline & Kawasan karst (persen) & 0,2200 & 0,2200 & 0,0049 & 0,0049 & 0,0000 & 0,0000 & 0,2851 & 0,2851 \\
\hline & Kawasan risiko bencana (persen) & 0,0000 & 0,271 & 0,0131 & 0,0131 & 0,3899 & 0,3899 & 0,1178 & 0,1178 \\
\hline & Vol. Sampah terangkut/hari (persen) & 0,3599 & 0,8 & 0,752 & 0,79 & 0,5457 & 0,618 & 0,7119 & 0,7119 \\
\hline \multirow{6}{*}{ 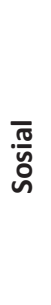 } & Perceraian & 0,00736 & 0,01032 & 0,0113 & 0,0114 & 0,0102 & 0,0118 & 0,00952 & 0,01147 \\
\hline & Akseptor KB Aktif & 0,13071 & 0,12322 & 0,15580 & 0,15059 & 0,12010 & 0,11653 & 0,09800 & 0,08422 \\
\hline & LPM & 0,0001 & 0,0001 & 0,0001 & 0,0001 & 0,0001 & 0,0001 & 0,0001 & 0,0001 \\
\hline & Kriminalaitas & 0,0044 & 0,0041 & 0,0039 & 0,0037 & 0,0041 & 0,0040 & 0,0025 & 0,0023 \\
\hline & Kecelakaan lalu lintas & 0,0004 & 0,0002 & 0,0002 & 0,0002 & 0,0003 & 0,0002 & 0,0003 & 0,0002 \\
\hline & Penduduk usia produktif & 0,4878 & 0,4592 & 0,4738 & 0,4831 & 0,4383 & 0,4483 & 0,3874 & 0,3784 \\
\hline
\end{tabular}

Keterangan: Dianalisis dari Tabel 5. 


\section{Lampiran 3:}

Tabel 7. Hasil Analisis Regional Sustainable Account (RSA) Wilayah Perkotaan di Provinsi Kalimantan Timur Tahun 2014 dan Tahun 2015

\begin{tabular}{|c|c|c|c|c|c|c|c|}
\hline & \multirow{3}{*}{ Indikator } & \multicolumn{6}{|c|}{$\mathrm{RSA}= \pm \frac{\mathrm{Fxy} / \mathrm{Fx}}{\mathrm{F}_{\mathrm{y}} / \mathrm{F}_{\mathrm{m}}}$} \\
\hline & & \multicolumn{2}{|c|}{ Balikpapan } & \multicolumn{2}{|c|}{ Bontang } & \multicolumn{2}{|c|}{ Samarinda } \\
\hline & & 2014 & 2015 & 2014 & 2015 & 2014 & 2015 \\
\hline \multirow{8}{*}{$\begin{array}{l}\bar{\varepsilon} \\
\overline{\check{\varepsilon}} \\
\overline{0} \\
\overline{\dot{u}}\end{array}$} & Pengangguran & $-1,0024$ & $-0,7930$ & $-1,2438$ & $-1,6086$ & $-1,0024$ & $-0,7477$ \\
\hline & Kemiskinan & $-0,3896$ & $-0,4721$ & $-0,8106$ & $-0,9728$ & $-0,7274$ & $-0,8727$ \\
\hline & Belanja rumah tangga & 1,7395 & 1,5906 & 0,4865 & 0,4662 & 3,1413 & 2,7857 \\
\hline & Kontribusi pertambangan & $-0,0010$ & $-0,0011$ & $-0,0335$ & $-0,0239$ & $-0,3047$ & $-0,2768$ \\
\hline & Kontribusi pertanian & 0,1429 & 0,1333 & 0,1100 & 0,1187 & 0,2214 & 0,2320 \\
\hline & Kontribusi jasa kesehatan & 1,2045 & 1,0727 & 1,0000 & 0,8727 & 2,5227 & 2,2000 \\
\hline & Kontribusi jasa pendidikan & 1,1356 & 1,0069 & 0,5339 & 0,4345 & 2,7627 & 2,4897 \\
\hline & Jumlah & 2,8295 & 2,5373 & 0,0425 & $-0,7132$ & 6,6136 & 5,8102 \\
\hline \multirow{9}{*}{ 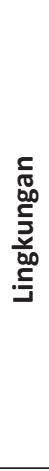 } & Kawasan hutan (persen) & 0,3247 & 0,3247 & 1,0490 & 1,0490 & 0,0759 & 0,0759 \\
\hline & Kawasan basah dan rawa (persen) & 0,2762 & 0,2762 & 0,3509 & 0,3509 & 1,1911 & 1,1911 \\
\hline & Lahan tidak kritis (persen) & 0,2768 & 0,2768 & 0,7208 & 0,7208 & 0,0655 & 0,0655 \\
\hline & Lahan kritis (persen) & $-5,6239$ & $-5,6239$ & $-3,1737$ & $-3,1737$ & $-3,4335$ & $-3,4335$ \\
\hline & Luas lereng $>40^{\circ}$ (persen) & $-0,8544$ & $-0,8544$ & $-0,7146$ & $-0,7146$ & $-0,2977$ & $-0,2977$ \\
\hline & Kawasan karst (persen) & 0,7717 & 0,7717 & 0,0173 & 0,0173 & 0,0001 & 0,0001 \\
\hline & Kawasan risiko bencana (persen) & 0,0000 & $-2,3003$ & $-0,1112$ & $-0,1112$ & $-3,3096$ & $-3,3096$ \\
\hline & Vol. Sampah terangkut/hari (persen) & 0,5055 & 1,1238 & 1,0563 & 1,1097 & 0,7665 & 0,8681 \\
\hline & Jumlah & $-4,3234$ & $-6,0054$ & $-0,8052$ & $-0,7518$ & $-4,9417$ & $-4,8401$ \\
\hline \multirow{7}{*}{$\begin{array}{l}\bar{\pi} \\
\frac{\pi}{n} \\
\stackrel{n}{ }\end{array}$} & Perceraian & $-0,7725$ & $-0,8997$ & $-1,1905$ & $-0,9978$ & $-1,0758$ & $-1,0283$ \\
\hline & Akseptor KB aktif & 1,3338 & 1,4632 & 1,5899 & 1,7881 & 1,2255 & 1,3837 \\
\hline & LPM & 0,5046 & 0,5084 & 0,8865 & 0,8880 & 0,6541 & 0,6576 \\
\hline & Kriminalaitas & $-1,7449$ & $-1,7491$ & $-1,5773$ & $-1,5920$ & $-1,6557$ & $-1,6844$ \\
\hline & Kecelakaan lalu lintas & $-1,4179$ & $-1,2619$ & $-0,9317$ & $-1,3304$ & $-1,0813$ & $-0,8891$ \\
\hline & Penduduk usia produktif & 1,2592 & 1,2136 & 1,2229 & 1,2766 & 1,1314 & 1,1848 \\
\hline & Jumlah & $-0,8377$ & $-0,7255$ & $-0,0002$ & 0,0325 & $-0,8018$ & $-0,3757$ \\
\hline & Jumlah E + L + S & $-2,3316$ & $-4,1936$ & $-0,7629$ & $-1,4325$ & 0,8701 & 0,5944 \\
\hline & Rata-rata & $-0,7772$ & $-1,3979$ & $-0,2543$ & $-0,4775$ & 0,2900 & 0,1981 \\
\hline
\end{tabular}

Keterangan: Dianalisis dari Tabel 6. 